\title{
Mozart's Figaro and Don Giovanni, Operatic Canon, and National Politics in Nineteenth-Century Prague
}

\author{
MARTIN NEDBAL
}

Between 1874 and 1916, the Czech opera ensemble in Prague celebrated the birthday of the Austro-Hungarian emperor Franz Joseph I every 18 August with a special opera performance preceded by the national anthem and accompanied by special, festive lighting. The choice of opera varied, but most often it was an original Czech work, most prominently one by Bedřich Smetana (his The Bartered Bride and Dalibor were performed on two occasions, Two Widows on three, and The Kiss on four). The only two foreign operas used by the Czech ensemble to celebrate their emperor more than once were Verdi's Ernani (in 1874 and 1880) and Mozart's Le nozze di Figaro (in 1876 and 1883). Whereas Ernani was most likely chosen for its depiction of the magnanimous Habsburg emperor Charles $\mathrm{V}$, Le nozze di Figaro symbolized important aspects of Czech cultural identity in relation to imperial Austria. Together with Don Giovanni (which was used to celebrate the Emperor in 1888), Mozart's Le nozze di Figaro has been considered one of the most important symbols of Bohemia's cultural and intellectual refinement ever since the late eighteenth century. In their reports about late-nineteenth-century Czech performances of Don Giovanni and Le nozze di Figaro, Prague's theater critics repeatedly mention the festive, celebratory atmosphere that supposedly electrified the audiences in the theater. ${ }^{1}$ For over two centuries, more-

\footnotetext{
${ }^{1}$ This is the case especially with the reviews of Le nozze di Figaro at the Provisional Theater between 1865 and 1883 in the journals Naše listy, Národní listy, and Politik, as well as the musical magazines Dalibor and Slavoj. Some reports are so enthusiastic as to exaggerate the festivity of the performances. For example, in his review of the first performance of Le nozze di Figaro at the Provisional Theater on 26 January 1865 in Národní listy, Bedřich Smetana complains that the attendance was not very high, whereas the more conservative journal Politik announces that the audience appeared in quite large numbers. "Divadlo. 'Figarova svatba' od Mozarta," Národní listy, 28 January 1865 and "Theater: Böhmische Oper," Politik, 28 January 1865.
} 
over, numerous Bohemian critics and musicologists have pointed out that it was only in Prague that Mozart's masterpieces could receive the acclaim they truly deserved; in connection to Le nozze di Figaro, the critics emphasized gleefully that in Vienna the opera was more or less shunned and even overshadowed by the temporary success of Martin y Soler's Una cosa rara. ${ }^{2}$ For nineteenth-century Prague's intellectuals, enthusiastic reception of Mozart's Figaro and Don Giovanni and the narratives about the misunderstood genius finding muchneeded solace in Prague soothed the pain of living in a city of ancient glory that was nevertheless of secondary importance ever since the Habsburg emperors moved their court to Vienna in the early seventeenth century.

Besides the ambiguous relationship to Vienna and the Habsburg imperial institutions, the reception of Le nozze di Figaro and Don Giovanni in nineteenth-century Prague also reflected the processes by which the city's increasingly alienated Czech and German communities constructed their national and ethnic identities. ${ }^{3}$ In their discussions of Mozart, early-nineteenthcentury Czech cultural elites viewed the German element as alien to the essence of Bohemia, despite the benefits and support they received from Bohemian-German institutions. Prague's German-speaking elites, by contrast, embraced the concept of so-called utraquist patriotism, according to which Bohemia was a region with two languages that could nevertheless be unified by a single cultural identity. Yet, for many German-speaking intellectuals this Bohemian identity was based on the preeminence of the

\footnotetext{
${ }^{2}$ See, for example, the review of Smetana's 1868 production of Le nozze di Figaro at the Provisional Theater in "Literatura a uméní. Divadlo," Naše listy, 10 November 1868. The fact that Figaro was more successful in Prague than in Vienna appears already in Niemetschek's 1798 biography, though Niemetschek ascribes the failure of the opera in Vienna to the intrigues of the Italian singers. See Franz Xaver Niemetschek, Lebensbeschreibung des k. $k$. Kapellmeisters Mozart, aus Originalquellen (Prague, 1798), 25. Also, Paul Nettl discusses the fact that Figaro was not very successful in Vienna in Mozart in Böhmen (Prague: Neumann, 1938), 81.

${ }^{3}$ An overview of the more or less subtle shifts in the understanding of the term "nation" in early-nineteenth-century Bohemia can be found in Pieter Judson, The Habsburg Empire: A New History (Cambridge: Belknap Press, 2016),
} 85-88.
German language, which they viewed as more advanced, universal, and therefore superior to the Czech language. Late-nineteenth-century Czech and German productions of Le nozze di Figaro and Don Giovanni, furthermore, illustrate the rise of exclusively ethnic viewpoints that made cultural exchange between the two groups nearly impossible.

Philipp Ther has placed the beginning of intense national appropriations of Mozart and other "classics" in Prague into the 1880s, but in fact the process started much earlier. ${ }^{4}$ For Prague's German speakers the two operas became powerful symbols of regional identity from the late eighteenth century on, particularly in relation to other German communities in Central Europe. By contrast, those attempting to establish modern Czech language and culture in the 1820s used Mozart and his operas to overcome German artistic and intellectual dominance and establish a classical basis for national forms of artistic expression. An invaluable resource for the study of Mozart reception in nineteenth-century Prague is the collection of theater posters in the Czech $\mathrm{Na}$ tional Museum, which scholars have previously studied only as a source of information about Czech-language, not German-language culture of Prague. ${ }^{5}$ The specificities of Czech and German approaches to Le nozze di Figaro and Don Giovanni throughout the nineteenth century are also illuminated by libretto translations and conducting and prompter's scores associated with Prague's productions of the operas between 1825 and 1887 and preserved in Prague's archives.

Beyond elements pertaining specifically to the history of Bohemian culture, the reception of Le nozze di Figaro and Don Giovanni in

${ }^{4}$ Philipp Ther, Center Stage: Operatic Culture and Nation Building in Nineteenth-Century Central Europe, trans. Charlotte Hughes-Kreuzmüller (West Lafayette, IN: Purdue University Press, 2014), 239.

${ }^{5}$ These posters were the main resource for Miroslav Laiske's list of the Czech, not German, theater repertoire in Prague up to 1862. Miroslav Laiske, Pražská dramaturgie: Česká divadelní představení v Praze do otevření Prozatimního divadla, 2 vols. (Prague: Ústav pro českou a světovou literaturu ČSAV, 1974). Many thanks to Markéta Trávnícková and Kryštof Vanča from the Czech National Museum for their assistance in researching this poster collection. 
nineteenth-century Prague also reveals strong but often complicated links between nationalism and the processes of constructing the musical, and more specifically operatic, canon. Ever since Lydia Goehr's seminal study, The Imaginary Museum of Musical Works, scholars have been exploring the connections between musical canons and the concept of musical autonomy. ${ }^{6}$ William Weber and Mark Evan Bonds, for example, have discussed some of the political aspects behind musical canons' constructions. ${ }^{7}$ But as Roger Parker has pointed out, few studies exist that address the role opera played in the rise to prominence of the idea that musical culture consists predominantly of autonomous musical works that need to be continually displayed in performance spaces similar to museum objects. ${ }^{8}$ Furthermore, most scholars who explore the formation of the operatic canon in connection to national politics focus on the second half of the nineteenth century. ${ }^{9}$ Rachel Cowgill's study of early-nineteenth-century Mozart reception in London shows that workoriented approaches to Mozart's operas became prominent in the British capital in the 1820s but were connected purely to commercialism and Romantic aesthetics, not politics and social issues. ${ }^{10}$ Yet, in Prague, Le nozze di Figaro

\footnotetext{
${ }^{6}$ Lydia Goehr, The Imaginary Museum of Musical Works: An Essay in the Philosophy of Music, rev. edn. (New York: Oxford University Press, 2007).

${ }^{7}$ William Weber, The Great Transformation of Musical Taste: Concert Programming from Haydn to Brahms (New York: Cambridge University Press, 2008), esp. 213-14; and Mark Evan Bonds, Absolute Music: The History of an Idea (New York: Oxford University Press, 2014), esp. 287-88.

${ }^{8}$ Roger Parker, Remaking the Song: Operatic Visions from Berio to Handel (Berkeley: University of California Press, 2006), 3.

${ }^{9}$ See Katherine Ellis, "Systems Failure in Operatic Paris: The Acid Test of the Théâtre-Lyrique," in Stage Music and Cultural Transfer, Paris 1830-1914, ed. Mark Everist and Annegret Fauser (Chicago: University of Chicago Press, 20091, 49-71; Weber, The Great Transformation of Musical Taste, 276; Jutta Toelle, "Venice and Its Opera House: Hope and Despair at the Teatro la Fenice, 1866-1897," Journal of Musicological Research 26 (2007): 33-54; John Rosselli, "Italy, The Decline of a Tradition," in The Late Romantic Era from the Mid-Nineteenth Century to World War I, ed. Jim Samson (London: Macmillan, 1991), 126-50.

${ }^{10}$ Rachel Cowgill, "Mozart's Productions and the Emergence of Werktreue at London's Italian Opera House, 17801830," in Operatic Migrations: Transforming Works and Crossing Boundaries, ed. Roberta Montemorra Marvin and Downing Thomas (New York: Ashgate, 2006), 145-86.
}

and Don Giovanni had achieved canonic status already in the late eighteenth century: Mozart's operas received more performances in Prague than elsewhere, Prague became an important center for producing commercial copies of Mozart's operas, and certain Prague intellectuals attempted to create "definitive" versions of these works (see below). ${ }^{11}$ In the late 1700s, however, in Prague as elsewhere in Europe, the original forms of Mozart's operas were often replaced in performance by various adaptations that more or less departed from how Mozart and $\mathrm{Da}$ Ponte originally conceived the works. This article explores how nineteenth-century Prague's intellectuals and artists started to turn away from these adaptations in attempts to construct and sharpen the image of Le nozze di Figaro and Don Giovanni as semi-autonomous musical works to be presented in forms that were as close as possible to what was deemed the venerated author's original idea. I will also show that in Prague the emergence of conceptualizations of operas as autonomous works and the attendant idea of Werktreue (i.e., fidelity to an authoritative score or text) were closely related to the rise of patriotic and nationalist sentiments.

\section{Werktreue and Patriotism in Prague Mozart Productions}

Ian Woodfield has suggested that the concept of Werktreue was important already in the first Prague productions of Le nozze di Figaro (1786) and Cosi fan tutte (1791). Woodfield shows that the editor(s) of the Prague librettos did not merely copy the published Vienna librettos but incorporated textual changes executed by Mozart in the autographs and the Vienna conducting scores. ${ }^{12}$ At the same time, however,

\footnotetext{
${ }^{11}$ On the concept of fidelity to authoritative versions of $L e$ nozze di Figaro and Così fan tutte in late-eighteenth-century Prague, see Ian Woodfield, "Werktreue in the Prague Productions of Le nozze di Figaro (1786) and Cosi fan tutte (1791)," Mozart-Jahrbuch (2012): 245-66. On Prague as a distributing hub of commercial scores of Mozart's operas, see Milada Jonášová, "Prager Abschriften von Mozarts Kompositionen als Druckvorlagen in der ersten Hälfte des 19. Jahrhunderts," Mozart-Jahrbuch (2011): 18997, and "Die Zauberflöte, Il flauto magico, Kouzelná flétna-alles aus Prag," Mozart Studien 24 (2016): 49-92. ${ }^{12}$ Woodfield, "Werktreue," 246-55.
} 
the Prague conducting score of Così fan tutte and other musical scores of Le nozze di Figaro and Così fan tutte based on Prague sources sometimes change the text and music of Mozart's original setting to comply with the poetic text of Da Ponte's published libretto-to the point that in some passages the edited texts in these scores clash with Mozart's music, which is then adjusted. ${ }^{13}$ It is as if Prague's editors of the late 1700s wanted to create musical and poetic texts that were equally reverential to both Mozart and Da Ponte. The purpose of these textual revisions is not entirely clear. Woodfield suggests that through them the directors of Prague's opera company might have been trying to demonstrate their ability to faithfully re-create the operas originally written for Vienna, the imperial capital, on a provincial stage in Prague. ${ }^{14}$ Another possibility is that the detailed editorial changes in the texts of the two Mozart operas were in fact meant to distinguish Prague's productions from the Viennese ones, and possibly show Prague as the place where fidelity to the original ideas of the composer and the librettist was of upmost importance. Such an understanding would be consistent with the fact that many late-eighteenth-century Prague intellectuals subscribed to a sense of cultural rivalry with Vienna, emphasized superior operatic tastes in Prague as opposed to Vienna, and used purportedly problematic content of operas imported from Vienna as proof of Prague's cultural superiority. The author of a series of anonymous theater reviews published between 1794 and 1798 in the Brno magazine Allgemeines europäisches Journal, for example, continually criticized the lack of taste and morality in Viennese operatic works produced in Prague. ${ }^{15}$

One aspect of this critical discourse was an emphasis on the importance of performing "au-

\footnotetext{
${ }^{13}$ Ibid., 255-59. For a discussion of some of the musical adjustments in the Prague conducting score of Così fan tutte, see Martin Nedbal, "Domenico Guardasoni's Prague Conducting Score of Cosi fan tutte," Newsletter of the Mozart Society of America 21, no. 2 (Fall 2017): 5-10.

${ }^{14}$ Woodfield, "Werktreue," 262.

${ }^{15}$ The anti-Viennese bent of these reviews is discussed in Tomislav Volek, "Repertoir Nosticovského divadla v Praze $z$ let 1794, 1796-98," Miscellanea musicologica 16 (1961): $8-9$.
}

thentic" versions of Mozart's operas as opposed to later adaptations, particularly those that were seen as originating in Vienna. For example, in 1796 the Allgemeines europäisches Journal complained about the German production of Don Giovanni (under the title Don Juan) at the Nostitz (later Estates) Theater; the critic noted with displeasure both the interpolation of spoken dialogue and the fact that the Prague production left out the scena ultima. The new ending, in which Don Giovanni is dragged to hell and the remaining characters are not allowed to appear on stage to conclude the work with reflection and moralizing, was by then quite common on other Central European stages, including most likely the Vienna court theater during the 1788 production of Mozart's opera. For the Prague critic, however, such an ending smacked of popular spectacles, such as Faust plays, where the audience "could not applaud enough the devils who took the poor Faust in his grand despairing attitude and carried him triumphantly to hell" (wo man die Teufeln nicht genug beklatschen konnte, wenn sie recht höllenmässig den armen Faust in seiner grössten Attitude der Verzweiflung pakten, und trimphirend [sic] davon trugen). ${ }^{16}$ A similar expression of a sensitivity to Werktreue appears in an 1808 report from the Allgemeine musikalische Zeitung about the Estates Theater's singspiel production of Così fan tutte, under the title Mädchentreue. The 1808 Prague singspiel version was based on an adaptation prepared by Friedrich Treitschke for the 1804 production of the opera at the Vienna court theater. One aspect of this adaptation was the tendency to curtail morally problematic passages, such as Dorabella's aria "È amore un ladroncello," which Treitschke transformed from a suggestive celebration of erotic love to a warning against infidelity. ${ }^{17}$ The Prague correspondent noted with displeasure that the

\footnotetext{
${ }^{16}$ "Prag. Aufgeführte Stücke im k. k. Nazionaltheater im Monat November 1796," Allgemeines europäisches Journal 3, vol. 11 (December 1796): 190. Transcribed in Volek, "Repertoir," 84.

${ }^{17}$ Treitschke's adaptation is discussed in Martin Nedbal, "František Šír's First Czech Translation of Mozart's Final Opera Buffa and the Reception of Così fan tutte in Prague 1791-1831," Divadelní revue 27, no. 2 (Fall 2016): 56-57.
} 
Treitschke/Prague version of the aria was devoid of "the jocund and romping wit that comes so pleasantly and charmingly to the fore in this erotic aria." 18 The critic also complained that in the second-act finale the Prague version (in imitation of Treitschke's Vienna version) cut the $\mathrm{A} b$-major canon, although Prague's audiences were used to it from the Italian production of the opera that continued to be performed until 1807. From the late eighteenth century on, Prague's critics constructed an image of unusual sensitivity their city's audience had for such versions of the Mozart-Da Ponte operas that were as close as possible to what was viewed as the composer and librettist's original conception. This sensitivity to Werktreue in Mozart's productions had a patriotic component because it helped construct an image of Prague's theatergoing public as possessing delicate tastes and a special understanding of Mozart's music.

The tendency to strive for Werktreue in Prague's Mozart opera productions acquired a specifically nationalist subtext in the 1820 s in connection to the process of the so-called Czech national revival, in which a group of intellectuals attempted to create a body of literary and theatrical works in the Czech language. Although Mozart's operas were popular in Prague from the 1780s on, Czech performances were rare. Instead, Mozart's operas were mainly performed in Italian and German, which temporarily became the only theater language used in Prague after the Italian opera company disbanded in 1807 following the death of the impresario Domenico Guardasoni in 1806. Czech performances of Mozart's operas started with Die Zauberflöte in 1794, followed by Die Entführung in $1806 .{ }^{19}$ The heyday of Czech

\footnotetext{
${ }^{18}$ "Prag, d. 5ten Febr.," Allgemeine musikalische Zeitung 10, no. 26 (23 March 1808): 410.

${ }^{19}$ These productions are discussed in Dějiny českého divadla, ed. František Černý, vol. 2, Národní obrození (Prague: Československá akademie věd, 1969), 66-76. On Die Zauberflöte, see also Tomislav Volek, "Die erste Aufführung der 'Zauberflöte' in der tschechischen Sprache in Prag 1794," Mozart-Jahrbuch 15 (1967): 387-95. The choice of the two singspiels with their more straightforward music and spoken dialogue must have been related to the social structure of Czech audiences at the turn of the nineteenth century. Whereas Prague's aristocracy and educated bureaucracy was predominantly German-speak-
}

Mozart productions came in the 1820s when a new triumvirate of managers (consisting of Jan Nepomuk Štěpánek, František Polawský, and Joseph Kainz) established regular Czech opera performances at the Estates Theater. One of the most highly publicized theatrical events of the national revival in the 1820s was the first Czech production of Don Giovanni at the Estates Theater, which premiered on 9 April 1825. The author of the Czech adaptation used in this production, Jan Nepomuk Stěpánek, mostly followed Friedrich Karl Lippert's 1798 Viennese revision of the opera's plot, which was also used in Prague's German productions in the first half of the nineteenth century. Into the 1825 Czech adaptation of Da Ponte's original story Štěpánek included Lippert's two interpolated scenes, in which Don Juan outwits a merchant to whom he owes money and several constables, who come to question him about the murder of Donna Anna's father. These two scenes were dropped from the Czech Don Juan as early as its second performance (on 20 November 1825), whereas they remained in the Prague German Don Juan until the mid-1830s. It is possible that the cut of these two scenes initially had to do with time limitations on Czech performances, which could occur only as Sunday or holiday matinées and had to fit into two hours so that the evening German performances would not have to be curtailed. ${ }^{20}$ As the poster shows, the premiere performance of the Czech Don Juan on April 9 did not have to be curtailed, however, because it exceptionally took place on a Saturday evening, possibly because it was a charity event, the proceeds of which went to support an almshouse in Prague (plate 1). In an 1827 review of the Czech Don

ing and frequented the fashionable Italian and German performances (including Italian and German versions of Le nozze di Figaro and Don Giovannil, Czech was the language of the uneducated working class, to whom the folksy singspiels with spoken dialogue must have appealed more than opere buffe.

${ }^{20}$ The limited amount of performances in Czech went back to the early nineteenth century and had to do with the fact that at that time Prague's elites did not think of Czech as a language of education and culture. The process of establishing the rules limiting Czech performances to Sunday and holiday afternoons is described in Jan Vondráček, Déjiny českého divadla 1771-1824 (Praha: Orbis, 1956), 292-300.
MARTIN NEDBAL

Figaro and Don Giovanni in

Prague 
Plate 1: Poster for the first performance of the Czech Don Juan on 9 April 1825.

Prague, National Museum, Theater Department, H6C-17513, published with permission. 
Juan, the Czech theater critic Josef Krasoslav Chmelenský reinterpreted the excision of the extra characters in national terms when he emphasized that they were "incorporated only later by the Germans" (pozděgi od Němcůw přiwtělené), and that their removal was welcomed by the "more educated" members of the audience. ${ }^{21}$

In the same article, Chmelenský complained about the opera's ending; the Czech production, similar to most nineteenth-century performances of Don Giovanni, omitted the scena ultima. ${ }^{22} \mathrm{Chmelenský} \mathrm{attributed} \mathrm{the} \mathrm{shortened}$ second-act finale to German practices, and expressed the hope that Štépanek and his troupe would restore it, so that the Czech production could present the opera as it had appeared under Mozart's direction four decades earlier. As if in response to Chmelenský's request, on 28 October 1827, the Czech company announced for the next day a performance of usually omitted musical numbers from the second act of Don Giovanni, including the scena ultima. The performance of the full second act eventually occurred only on 3 February 1828, as shown by theater posters from the Czech National Museum collection. The poster for the 3 February performance (plate 2) emphasizes the idea of the Czech performance's historical authenticity by claiming that the musical numbers had not been heard since the times of the Italian opera company ("se wssemi zpěwy, gakžse za času wlaské zpěwohry prowozowali" / "mit allen Gesängen, wie sie zur Zeit der italienischen Opern gesungen wurden"). The Czech troupe here aligns itself with the cosmopolitan world of Prague's opera prior to 1807, before German became the only language heard on Prague's professional stages for more than a decade.

At the same time, the attempts at authenticity in the Czech Don Giovanni were not exclusively anti-German. In his next article about Czech theater, Chmelenský proudly reports that many German opera lovers attended the Febru-

${ }^{21}$ Chmelenský, "Diwadlo české roku 1827," Časopis českého Museum 1, no. 2 (1827): 139-40.

${ }^{22}$ Ibid., 140. ary performance to hear the unknown parts of the opera. ${ }^{23}$ Chmelenský's report is important because it shows not only the connection between "authenticity" and national pride, but also the inclusiveness of Czech opera performances, where German audiences were apparently embraced and welcome. Such an approach coincides with the way in which the historian Gary Cohen conceptualizes national identity in early-nineteenth-century Prague. Prague's Czech intellectuals both developed "a consciousness of their membership in a distinct Czech nation" and embraced "a Bohemian patriotism that desired to further the interests of all the people in the kingdom, their greater political autonomy, and the development of both Czech and German cultures." 24

In restoring the scena ultima, the Czech company went against the contemporary belief that ending Don Giovanni with the Don's journey to hell was not only more dramatic but also more audience friendly and beneficial for the box office. In an 1834 report on the new German production of Don Juan at the Estates Theater (the first under the direction of Johann $\mathrm{Au}$ gust Stöger), the Prague correspondent of the Wiener Zeitschrift complains that although Prague's admirers of classical art would like to hear the scena ultima, Stöger left it out. ${ }^{25}$ The reporter also discusses the spectacular elements of the 1834 second-act finale ending: after the departure of the Commendatore's ghost, Don Juan's room transformed into a "hellish maw" (Höllenrachen) containing a giant puppet with a wig of snakes and enormous eye balls that moved back and forth. The furies chased Don Juan into the side wings and the giant became illuminated by red spotlights and fireworks; the giant then reached into the fire and pulled out a lifeless effigy of Don Juan as the curtain was going down. ${ }^{26}$ Emphasizing the popular appeal

\footnotetext{
${ }^{23}$ Chmelenský, "Diwadlo české od 1ho dubna 1827 až do 16. máge roku 1828," Časopis českého Museum 2, no. 3 (1828): 125.

${ }^{24}$ Gary B. Cohen, The Politics of Ethnic Survival: Germans in Prague, 1861-1914, 2nd rev. edn. (West Lafayette: Purdue University Press, 2006), 22-23.

${ }^{25}$ "Correspondenz-Nachrichten. Prag, Anfangs August 1834," Wiener Zeitschrift, 19 August 1834.

${ }^{26}$ To accommodate all the spectacle, the scene with Don Juan and the infernal chorus was extended in Prague's performances, as becomes clear from the conducting score
} 
19 TH

CENTURY

MUSIC

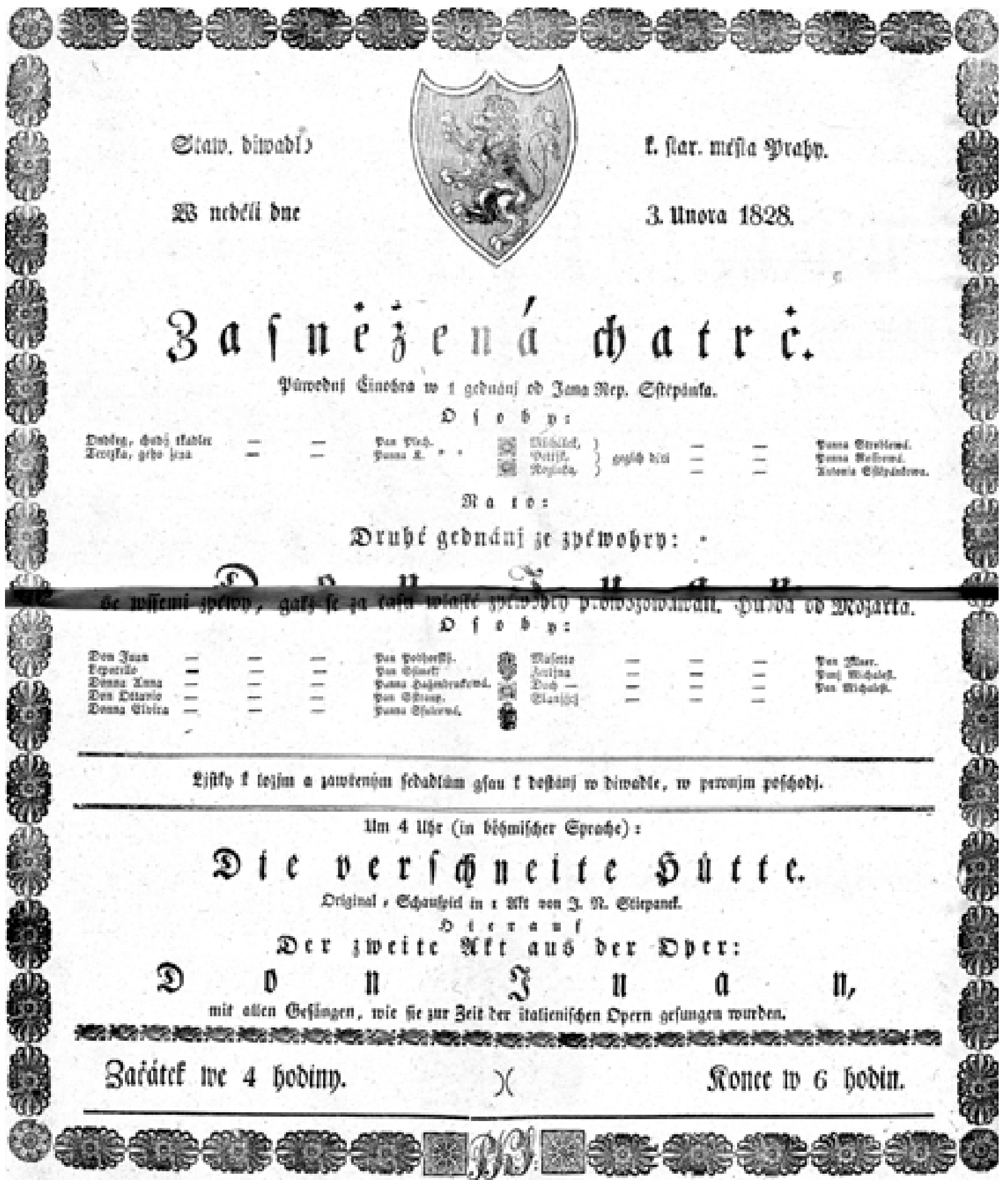

Plate 2: Poster for the Czech matinée performance of the second act of Don Giovanni at Prague's Estates Theater on Sunday, 3 February 1828. The first part of the matinée featured the play Zasněžená chatrě (Snowed-in Hut) by Jan Nepomuk Štěpánek, who was also the translator of Da Ponte's libretto. Prague, National Museum,

Theater Department, H6C-17518, published with permission. 
of such an ending, the reporter mentions that it was particularly the gallery (with the cheapest seats) that cheered during this passage. Anton Müller, the theater critic for the Prague journal Bohemia, admitted that although he was no fan of such over-the-top theatricality, he appreciated that it demonstrated the new theater direction's readiness to modernize older works and entice present-day audiences. ${ }^{27}$ Thus nearly a decade after the Czech opera company embraced Werktreue for national purposes, the German company continued to indulge "modernizing" approaches to attract spectators.

\section{Czech Mozart Libretto \\ Translations and National IDENTIty}

The 1825 Czech Don Juan was produced by a semi-professional Czech opera company that started its activities in the Estates Theater in December of 1823 with a performance of Joseph Weigl's Die Schweizerfamilie. In the following decade, the Czech ensemble produced numerous operas, including four Mozart works: Don Juan in 1825, Die Zauberflöte and Die Entführung aus dem Serail in 1829, and Così fan tutte in $1831 .{ }^{28}$ The librettos of Mozart operas were, for the most part, translated by members of the intellectual circle around Josef Jungmann (1773-1847), an important early-nineteenth-century Czech poet and linguist. In the 1820s, Jungmann himself translated into Czech the libretto of Die Entführung aus dem Serail, whereas his colleagues and friends, František Šŕr, Karel Simeon Macháček, and Josef Krasoslav Chmelenský, translated Cosi fan tutte, Don Giovanni, and Die Zauberflöte. Besides the translations themselves, a major source of information about the Czech Mozart translations from the $1820 \mathrm{~s}$ is the correspondence of Jungmann's son Josef Josefovič (J. J.) Jungmann. ${ }^{29}$

used throughout the 1820s and 1830s (the Donebauer score, now in the Prague Conservatoryl, where a note in pencil calls for two repeats of the final nine measures $(\mathrm{mm}$. 596604).

27"Theater und geselliges Leben. Theaterbericht vom 12 . und 13. Juli," Bohemia, 15 July 1834.

${ }^{28}$ Černý, Dějiny českého divadla, 152.

${ }^{29} \mathrm{~J}$. J. Jungmann, Korespondence, ed. Olga VotočkováLauermannová (Prague: Státní nakladatelství krásné literatury, hudby a umění, 1956).
The members of the Jungmann circle had a rather difficult task in creating Mozart libretto translations at a time when Czech language was not yet completely standardized and few people knew how to read and write it. Moreover, these translations were being undertaken in spite of the fact that there was no real tradition of opera in Czech-in 1823, when the circle started the translation project, not a single original opera in Czech existed. In the absence of any tradition to fall upon, the Jungmann circle embraced the quantitative verse system (the so-called časomíra), where the metric patterns of individual lines were decided by long and short syllables. ${ }^{30}$ This system became popular with Czech intellectuals especially after František Palacký and Pavel Josef Šafařík published the treatise Počátkové českého básnictví, obzvláště prozódie (The Origins of Czech Verse, Especially Prosody) in 1818. The main idea of the treatise was that whereas German poetry relies on a "syllabotonic" or accentual metric system, where poetic feet are determined by word accents, Czech poetry should rely on both accents and lengths of syllables to imitate the poetry of the ancient Greeks. An important part of Palacký and Šafařík's argument was that časomíra would bring out the innate musicality of the Czechs, especially in comparison to the "non-musical Germans" (nehudební Němcové). ${ }^{31}$ The four Mozart translations by members of the Jungmann circle closely follow these ideas by employing mainly, though not exclusively, quantitative verse.

J. J. Jungmann's letters show, furthermore, that the creation of the translation was accompanied by intense discussions about the nature of the Czech language and operatic poetry, close examinations of musical scores, and fidelity to Da Ponte's text. In an undated letter, most likely from 1824, to the Eastern Bohemian poet and translator Antonín Marek, Jungmann outlines the sophisticated preparations that members of the circle took before embarking on a

\footnotetext{
${ }^{30}$ For basic background on this metric system, see John Tyrrell, Czech Opera (New York: Cambridge University Press, 1988), 257.

${ }^{31}$ František Palacký and Pavel Josef Šafařík, Počátkové českého básnictví obzvláště prozódie, ed. Karol Rosenbaum (Bratislava: Slovenská akadémia vied, 1961), 47.
}

Prague 
translation. ${ }^{32}$ Jungmann unsuccessfully tries to persuade Marek to translate into Czech Le nozze di Figaro and promises to send a vocal score with Italian and German texts as well as an Italian libretto. The Czech version of Così fan tutte by Śír shows, furthermore, that although the translator worked with a German score containing occasional musical adjustments to fit the German syllabification, he also followed the Italian libretto and tried to stay closer to its meaning than the German translation. ${ }^{33}$ Similarly, Macháček, the translator of Don Giovanni, followed Da Ponte's original libretto, despite taking cues from Rochlitz's 1801 German translation. In a letter from 8 January 1825 to Šír, moreover, J. J. Jungmann comments on Šír's translation of Cosi fan tutte, finished in late $1824 .{ }^{34}$ Jungmann is impressed about how close Šir's translation is to Da Ponte's original, though he suggests changes that would make it more musical, for example by adding more words containing sonorous consonants, especially "á." The Czech Mozart translations of the 1820s were therefore highly sophisticated; they reflected contemporaneous debates about Czech language and poetry and incorporated ideas from various German literary efforts to adapt Mozart's Italian operas, but they also paid attention to the Italian originals. The importance of Mozart for the early-nineteenth-century attempts at reviving, standardizing, and modernizing the Czech language also shows how integral the composer was to the formation of modern Czech national identity.

\section{Prague Don Juan Productions IN THE I 83 OS AND I 840 S}

The impulse to embrace Werktreue eventually became prominent in Prague's German approaches to Don Giovanni, though the leanings toward historicist authenticity were not as intense and for the most part remained attached to the more generic Bohemian patriotism. The first time the German company rein-

\footnotetext{
${ }^{32}$ Jungmann, Korespondence, 64.

${ }^{33}$ Šír's translation is discussed in Nedbal, "František Šír's First Czech Translation."

${ }^{34}$ Jungmann, Korespondence, 88.
}

stated elements usually omitted from the Prague singspiel versions was during the festive performance celebrating Don Giovanni's fiftieth anniversary on 4 November $1837 .{ }^{35}$ According to the theater poster for that day, the numbers not usually performed in the Prague German Don Juan were Donna Elvira's "Ah fuggi il traditor" and "Mi tradì quell'alma ingrata," Don Ottavio's "Dalla sua pace," Masetto's "Ho capito, signor sì," Leporello's "Ah pietà, signori miei," Zerlina and Leporello's duet "Per queste tue manine," and the scena ultima. The inclusion of the extra musical numbers also forced the opera producers to cut the interpolated spoken dialogue scenes with the merchant and the constables for the first time since 1808 .

The idea for the German performance of an "authentic" Don Juan was motivated by not only the anniversary but also questions of patriotic prestige. Throughout 1837, a group of Prague's musicians and intellectuals collected finances for a Mozart monument. ${ }^{36}$ In one of the articles published in Bohemia in support of the effort, Anton Müller claimed that although such monuments were usually established in the cities of birth or long-time residence of famous composers, Prague was the place where Mozart's music was celebrated earlier than elsewhere and therefore represented the logical center for the future cultivation of Mozart's legacy. ${ }^{37}$ Müller also explained that since Mozart was a universally accepted master, all other cultured nations should contribute to the building of the Prague monument. An important part of the monument was also supposed to be a fund sponsoring "Mozart awards," monetary prizes given to authors of outstanding patriotic

\footnotetext{
${ }^{35}$ The exact date of Don Giovanni's premiere remained a matter of contention for some time. Until about 1847 Prague's elites believed that Don Giovanni was first performed on 4 November 1787. This opinion started to change around the time of the sixtieth anniversary of the opera, as becomes clear from a short notice in Bohemia from October of 1847, according to which the Wiener Zeitschrift reported that Don Giovanni was premiered on 28 October [sic], not on 4 November as was previously believed. "Mosaik," Bohemia, 12 October 1847.

${ }^{36}$ The general history of this institution is described in Marc Niubò, Moji Pražané mě uctívají: Mozarti̊v kult v Praze V 1. pol. 19. století a Mozartiov památník $V$ Klementinu (Prague: National Library, 2006), 11-12. 37"Telegraph von Prag," Bohemia, 10 February 1837.
} 
compositions. ${ }^{38}$ Since in the end only Prague's individuals and organizations contributed to the monument, the "Mozart award" fund never materialized, and the Mozart monument merely consisted of a Mozart bust by the sculptor Emanuel Max and two glass vitrines preserving scores of Mozart's compositions-all three items were displayed in the main hall of the royal and imperial library at the Prague University (presently the Czech National Library). In October of 1837, Johann Ritter von Rittersberg, one of the founders of the Mozart monument, called on the Estates Theater directors to restore all the original musical numbers to the Don Juan production and thus to celebrate Prague's Mozart heritage in an appropriate manner. ${ }^{39}$ The historically informed performance on 4 November 1837 was therefore a direct result of the patriotic efforts associated with the Mozart monument.

The "authentic" version of Don Juan received only a few performances. As music critics explained, the restored numbers did not please Prague's audiences. Müller claims that Masetto's "Ho capito, signor sì" was quite unpopular and one of Elvira's extra arias was too tedious because it delayed the action too much. ${ }^{40}$ Conspicuously Masetto's aria and Elvira's "Ah fuggi il traditor" are missing from the Prague Conservatory conducting score of Don Giovanni (the so-called Donebauer score), used at the Estates Theater throughout the first half of the nineteenth century-likely they were no longer performed at the Estates Theater in the following decades. ${ }^{41}$ The Prague correspondent to the Allgemeine musikalische Zeitung also claims that the scena ultima was dropped after a single performance on 4 November-the repeat performance on 5 November reverted to the con-

\footnotetext{
${ }^{38}$ "Theater und geselliges Leben," Bohemia, 21 January 1838. In a later issue, the directors of the Mozart Monument foundation explained that the "Mozart Award" was not necessarily meant to be awarded only to secular compositions, but to any work by a Bohemian composer. See "Erwiderung," Bohemia, 2 February 1838.

39"Telegraph von Prag," Bohemia, 31 October 1837.

40"Theater und geselliges Leben. Theaterbericht vom 4 und 5. November," Bohemia, 7 November 1837.

${ }^{41}$ Basic information about the score can be found in Milada Jonášová, "Guglers Edition der Don Giovanni-Partitur und seine Korrespondenz mit Smetana," Mozart Studien 17 (2008): 279-329.
}

clusion in hell. ${ }^{42}$ The $A m Z$ critic blames the lack of enthusiasm for the original ending on the singers, who were supposedly "unaccustomed" to the dramatic structure of the extra scene: Leporello seemed too comical when he promised to lead a virtuous life, Donna Anna and Don Ottavio's reunion was too upbeat considering the catastrophe they had just gone through, and the performer of Donna Anna did not know her role well enough. Conspicuously, no such problems are reported in the Czech press in connection to the earlier "authentic" performances of Don Giovanni in Czech. It is possible that the national pride of the emerging Czech movement silenced any objections to the dramatic unviability of the restored portions of the opera.

Another important milestone in the process of injecting authenticity into Prague's Mozart opera productions came in 1842, when the German opera company for the first time introduced Mozart's original recitatives into German-language performances. ${ }^{43}$ The decision to include recitatives might have been partially incited by the success of the production of Don Giovanni in the original Italian with recitatives, presented by the Prague Conservatory under the leadership of vocal pedagogue Giovanni Battista Gordigiani on 12 May $1842 .{ }^{44}$ In his enthusiastic review of the Conservatory production in Bohemia, Müller expressed his amazement at the intensity of artistic pleasure one could derive from hearing the work in the

\footnotetext{
42"Nachrichten. Prag," Allgemeine musikalische Zeitung 39, no. 49 (6 December 1837): 800.

${ }^{43}$ The recitatives were accompanied by a string quartet, not a keyboard, as explained by the theater critic in "Kunst und Leben in Böhmen. Theater," Bohemia, 28 January 1847. The score used during these performances was still the Donebauer score, the one from which Mozart supposedly conducted in 1787 and 1791. Into the score, new sheets with German recitatives and string quartet accompaniment were inserted, probably in 1842 . Niubò is not aware of the 1842 performances of recitatives and mentions only those from 1847. See Niubò, Moji Pražané mě uctívají, 35.

${ }^{44}$ This and other instances of Gordigiani's Italian Mozart productions with his Conservatory students are discussed in Tomislav Volek, "Mozartovy italské opery v nastudování Giovanni Gordigianiho," Hudební věda 38, nos. 3-4 (2001): 439-44; and Jitřenka Pešková, "Provádění Mozartových oper pražskou konzervatoří v první polovině 19. století," Hudební věda 38, nos. 3-4 (2001): 397-415.
} 
original form. ${ }^{45}$ But the inclusion of recitatives into the German production also had to do with cultural politics and patriotism. The new Prague Don Juan with recitatives opened on 4 September 1842, the date that also marked the completion and dedication of the Salzburg Mozart monument. The initial stages of establishing the monument started with financial donations and collections of funds by various European, predominantly German, associations throughout the late 1830s, the same period when certain Prague intellectuals attempted to establish the Bohemian Mozart monument. In 1837, during the celebrations of Don Giovanni's fiftieth anniversary, and in early 1838 , a debate developed in the pages of Bohemia about whether institutions and individual donors in Bohemia should devote funds to the Salzburg or the Prague monuments. Müller suggested that Prague should join other European cultural centers in showing appreciation of and providing financial contributions to Mozart's birthplace. But Müller's suggestion was rebuked by the Mozart monument committee members, bent on securing resources for their own enterprise. ${ }^{46}$ This divided attitude to Salzburg's emerging status as the main Mozart city might also be reflected in the Don Juan production of 1842. The announcement, published in Bohemia, of the September 4 performance on the one hand mentioned that it was dedicated to the support of the Salzburg festivities, and on the other hand stressed that Prague was the first city in Germany to restore the recitatives, the German text of which was created specifically for the Estates Theater. ${ }^{47}$ The 1842 Don Juan production therefore both linked Prague to the international Mozart cult but also emphasized its special position in the preservation of Mozart's legacy. ${ }^{48}$

${ }^{45}$ "Kunst und Leben in Böhmen. Theaterbericht vom 12. Mai," Bohemia, 14 May 1842.

${ }^{46}$ For Müller's suggestions about supporting the Salzburg endeavor, see his review of Così fan tutte in "Theater und geselliges Leben. Theaterbericht vom 19. Jänner," Bohemia, 21 January 1838. The committee's response was published in "Erwiderung," Bohemia, 2 February 1838, and Müller responded in "Zur Verständigung," Bohemia, 6 February 1838.

47"Telegraph von Prag," Bohemia, 2 August 1842.

${ }^{48}$ The German company must have once again in 1845 replaced the recitatives with spoken dialogue in the next
The restoration of the recitatives was in the next few years followed by further acts marked by an interest in historical authenticity growing out of national and patriotic concerns. After the end of Stöger's directorship in 1846, the Estates Theater came under the direction of Johann Hoffmann. Hoffmann presented a new production of Don Juan on 30 January 1847.49 To distinguish his production from Stöger's, Hoffmann's team transformed the ending of the opera, replacing the giant puppet of a demon with a rain of fire. In his two reviews of the production, Bohemia's new theater critic, Bernhard Gutt, hailed the reduction of overthe-top spectacle in the opera's conclusion, but also demanded that the Prague production return to the scena ultima and thus do justice to "the greatest German opera" (der größten deutschen Oper). ${ }^{50}$ In response to Gutt's request, Hoffmann's company indeed presented the scena ultima in the performance on 26 March $1847 . .^{51}$ It was possibly in response to the rising sentiments of nationalism and patriotism in Prague at the dawn of the revolutionary year 1848 that this time the original ending stuck and continued to be performed in Prague German Don Giovanni performances ever since. As late as 1857, Gutt's successor, Franz Ulm, celebrated Hoffmann's music director, the composer František Škroup, for his decision to reintroduce the recitatives "for the first time among all cities" (zum erstenmale

few years, because in 1847 the Prague correspondent for the Allgemeine musikalische Zeitung complains that, whereas the Czech performances use recitatives, the German ones rely on "the pitiful spoken dialogues" (die erbärmliche Prosa). "Nachrichten. Prag. (April und Mai.)," Allgemeine musikalische Zeitung 47, no. 26 (25 June 1845): 439. In her article about Mozart reception in early-nineteenth-century Prague, Michaela Freemanová uses this statement to claim that the Czech productions introduced the recitatives before the German ones-possibly because she was unaware of the German recitative use as early as 1842. Michaela Freemanová, "Bohemia in the Early 19th Century: The 'Second Life' of Wolfgang Amadeus Mozart," Hudební věda 50, nos. 1-2 (2013): 98.

${ }^{49}$ The premiere was originally announced for 19 January, then postponed till 26 January, and eventually took place on 30 January 1847 . The production is also discussed in Niubò, Moji Pražané mě uctívají, 35-36; and in Josef Plavec, František Škroup (Prague: Melantrich, 1941), 617.

50"Kunst und Leben in Böhmen. Theater," Bohemia, 4 February 1847.

${ }^{51}$ Niubò wrongly lists this performance date as 25 March 1847. 
unter allen Städten). ${ }^{52}$ The reviews of Gutt and Ulm suggest that some members of Prague's intellectual and artistic community connected the reintroduction of recitatives in the German theater's Don Iuan either to the nationalist idea of Don Giovanni as a specifically German opera or to the patriotic idea of Prague as a special site for Mozart veneration.

The Czech Don Juan productions kept abreast of the German attempts at Werktreue, although there were only about twelve Czech performances of the full work between 1830 and 1864, when the first Don Juan production opened at the first independent Czech theater institution, the Provisional Theater. ${ }^{53}$ Immediately after the German company introduced recitatives in September of 1842, the Czech company followed suit in their 3 November 1842 performance in the New Theater in Růžová Street. It is unclear whether throughout this period the Czech performances continued to include the scena ultima, as they did in the 1820s. But the scena ultima must have been included in at least one performance at the Provisional Theater in the 1860s. This becomes clear from an 1868 letter by Bedřich Smetana to Johann Bernhard Gugler, who was then working on a critical edition of Don Giovanni and thought Smetana might have had access to the original 1787 instrumental parts in the Provisional Theater archive. In the letter, Smetana writes that the Provisional Theater has not performed the scena ultima except during one Mozart festival. ${ }^{54}$ This must have been on 18 December 1865, and a review of this performance in Národní listy shows that the inclusion of the scena ultima was once again viewed as a matter of national prestige; the critic thanked the then-director Maýr for presenting the full second-act finale and educating the national audience about the full extent of

\footnotetext{
52"Franz Skraup," Bohemia, 10 December 1857.

${ }^{53}$ The number of performances does not include the instances when individual numbers from the opera were included in quodlibets throughout this period.

${ }^{54}$ The correspondence between Smetana and Gugler and the fact that most of the Don Giovanni performing materials from the Provisional Theater are now lost are discussed in Jonášová, "Guglers Edition der Don GiovanniPartitur und seine Korrespondenz mit Smetana," 289.
}

Mozart's masterpiece so beloved by the citizens of Prague. ${ }^{55}$

The historicist leanings of the Prague German Don Juan productions in the 1840s also might have affected the text of the Czech Don Juan performances. Two different Czech translations appeared in anticipation of the 1825 Czech premiere of Don Juan at the Estates Theater; one by Macháček, a member of the Jungmann circle, another by Štěpánek. Possibly because he was one of the directors of the Estates Theater at that time, it was Štépánek's, not Macháček's, translation that was used in the 1825 production. As a person involved in day-to-day operations of the theater, Štěpánek was much more practical in his approach to libretto translations than the members of the Jungmann circle and mainly used the accentuated metric system, which was closer to the language spoken by the common people frequenting the Czech performances. In general, Stěpánek also had the tendency to use coarser imagery that must have appealed to the less sophisticated Czech audiences, as becomes obvious from a comparison of Macháček's and Štěpánek's translations of Leporello's opening quatrain shown in Table 1. Already in the first quatrain, Štěpánek's image that the lack of sleep and food prevents one from becoming fatter contrasts with Macháček's more sophisticated metaphor of sowing and reaping. ${ }^{56}$ Štěpánek's earthy translation, however, remained in the Czech repertoire only for two decades. In 1845 the Czech opera company adopted the Ma-

\footnotetext{
55"Literatura a umění. Divadlo. Don Juan od Mozarta," Národní listy: Př́loha, 21 December 1865. The sensitivity of Prague's critics to "authentic" approaches to Mozart also drives Zikmund Kolešovský's critique of the 2 August 1862 Don Giovanni performance by Eugenio Merelli's Italian company. Kolešovský complains that the Italian company is excellent in performances of new Italian works but is unable to do justice to Mozartian classicism; he complains especially about the singers compensating for their bad intonation with a parlando style, getting lost in recitative passages, and transposing individual arias (Zerlina's "Batti, batti, o bel Masetto" was sung in E major, not the original $\mathrm{F}$ major). Zikmund Kolešovský, "Divadlo," Slavoj 1, no. 4 (14 August 1862): 84-85. See also Jitka Ludvová, Až k hořkému konci: Pražské německé divadlo, 1845-1945 (Prague: Academia, 2012), 152.

${ }^{56}$ The distinctions between the two translations are further discussed in Vojtěch Jirát, "Obrozenské překlady Mozartova Dona Juana," Slovo a slovesnost 4 (1938): 7390, 202-12.
} 
Štěpánek Translation

\section{Da Ponte}

Notte e giorno fatticar Per chi nulla sa gradir; Piova e vento sopportar Mangiar male e mal dormir.
Štěpánek

Ve dne, v noci neokřát $\mathrm{V}$ bouři běhat, $\mathrm{v}$ dešti stát, Špatně jíst a málo spát Odkud má se sádlo brát?
Štěpánek in English

Day and night no respite, To run in storm, and stand in rain, To eat poorly and sleep little, How can one get fatter?

Macháček's Translation

\section{Da Ponte}

Notte e giorno fatticar

Per chi nulla sa gradir.

Piova e vento sopportar, Mangiar male e mal dormir.
Macháček

Ve dne, v noci tak se hnát, V dešti, bouři dál se brát, Povždy sít a nikdy žát, Špatně jíst a málo spát.
Macháček in English

Day and night always in a rush, Always forward in thunder and rain, Always sow and never reap, To eat badly and sleep little. cháček translation, which then stayed in use until 1884. It is possible, furthermore, that the replacement of Štěpánek's translation with Macháček's had to do with a desire of the Czech performers to match the changes that the German opera company at the Estates Theater executed in its Don Juan performances. The Czech company adopted many elements from the German productions and might have also adopted the more refined Macháček translation in response to the German company's quest for authenticity.

The concern for Werktreue, so characteristic of how early-nineteenth-century Czech and German intellectuals and artists in Prague approached Mozart's operas, ran contrary to the composer's reception in Vienna and Paris. In Vienna, attempts at historical authenticity arrived later than in Prague. The reintroduction of recitatives into the Vienna court opera's production of Don Juan, for example, occurred only in 1858 , nearly two decades after Prague. ${ }^{57}$ The scena ultima was not performed in Vienna

${ }^{57}$ See Michael Jahn, Die Wiener Hofoper von 1810 bis 1836: Das Kärntnerthortheater als Hofoper (Vienna: Apfel, 2007), 76. throughout the whole nineteenth century, though this might have had to do with the fact that Mozart had cut it already in his Viennese revision of $1788 .{ }^{58}$ Similarly, nineteenth-century French-language performances took great liberties with the original operas. Most conspicuously, whereas throughout the 1820s and 30 s various Prague critics called for the restoration of the scena ultima to Don Giovanni, Parisian productions omitted it and, according to Katharine Ellis, the critics were not in the least bothered by that omission. ${ }^{59}$ Yet, as William Gibbons has shown, the more or less irreverent Paris adaptations were throughout the nineteenth century viewed as uniquely French because they erased the supposedly Germanic traits of the originals. ${ }^{60}$ Perhaps because the nineteenth-century musical canon was so closely linked to nationalism, it was still quite elastic and adjustable to local conditions; the

\footnotetext{
${ }^{58}$ Ibid.

${ }^{59}$ Katharine Ellis, "Rewriting Don Giovanni, or 'The Thieving Magpies,"' Journal of the Royal Musical Association 119 , no. 2 (1994): 249.

${ }^{60}$ William Gibbons, Building the Operatic Museum: Eighteenth-Century Opera in Fin-de-Siècle Paris (Rochester: University of Rochester Press, 2013), 39-44.
} 
same quest for Werktreue that was viewed as anti-German in the Czech production of Don Juan in the 1820s was perceived as too Germanic in Paris in the 1880s.

\section{The Czech Figaro of I 852}

Whereas Don Giovanni was a crucial work for the Czech cultural movement from the 1820s on, Le nozze di Figaro, which at first had a rather problematic existence in the Czech opera world, became a central work of the Czech repertoire in the 1860s, and it thus illuminates important aspects of mid-nineteenth-century cultural politics in Prague. Possibly because of the opera's large cast, the Czech opera ensemble did not attempt a production of Le nozze di Figaro until 1852, although the opera was continuously performed by the German company. The conditions for Czech culture and theater in Prague were quite different in the 1850s as opposed to the previous decades. In 1834 Johann August Stöger took over the directorship of the Estates Theater and devoted most resources to building a first-class German opera house. The Czech opera ensemble struggled during this period and focused on performances of quodlibets, or evenings of operatic excerpts, as opposed to full works. ${ }^{61}$ The number and quality of Czech opera performances decreased even further in the 1850s, when the struggling Czech ensemble focused most of its resources on spoken theater, and Czech cultural institutions faced obstructions from Austrian authorities bent on suppressing the nationalist sentiments that crystallized during the revolutions of $1848 .{ }^{62}$ And it was during this period, on 14 November 1852, that the Czech company in the predominantly German Estates Theater produced the very first Czech production of Le nozze di Figaro. Perhaps the use of Le nozze di Figaro for the opening of the 1852 Czech season was meant symbolically as a subtle reminder of the former glory of Czech and Bohemian culture

\footnotetext{
${ }^{61}$ See Tyrrell, Czech Opera, 23.

${ }^{62}$ Parallel changes in operatic repertoire occurred also in Vienna. As Ther points out, it was during the neo-absolutist 1850s that Italian opera made a comeback to the Vienna court opera as an expression of the new political importance of the imperial court. Ther, Center Stage, 17.
}

and an indirect protest against the political circumstances of the time.

In many ways, however, the 1852 Czech Figaro was a failure and reflected the relatively poor state of Prague's Czech opera in the midnineteenth century. The Czech adaptation received merely a single performance and was criticized mercilessly in the press. The critic of the Vienna Fremden-Blatt noted with sarcasm that although the Czech production was severely shortened, it left the audience wishing the whole opera were cut. ${ }^{63}$ These sentiments resonate with the views of Ferdinand Břetislav Mikovec, the theater critic for the Czech literary journal Lumir. Mikovec identifies as the Czech Figaro's greatest shortcoming the sorry state of the Czech opera ensemble. Apparently, the performance made use of only two professional opera singers, one of whom was miscast due to the missing personnel. Mikovec has the greatest praise for Franziska Wagner in the role of Susanna, but he expresses reservations about the famous Czech bass Karel Strakatý in the role of Figaro. Strakaty was cast as the eponymous character because there was no other qualified Czech singer who could take the lead, and although he was successful as Figaro, Mikovec notes that he might have been even more impressive as the Count, which was his customary role in German performances at the Estates Theater. Mikovec touches only briefly on the amateur performers and saves the sharpest criticism for Therese Mink in the role of the Countess. Mink was an actress in the German spoken-theater ensemble but was also cast in Czech opera performances, in spite of the fact that, as Mikovec complains, she did not have a good singing voice and therefore "torture[d] us with her croaking." 64 The 1852 performance also illustrates the continuing rel-

\footnotetext{
63"Allerlei. Prag," Fremden-Blatt, 18 November 1852.

${ }^{64}$ The review appeared in "Z Prahy. (České divadlo.)" Lumír 2 , no. 46 (18 November 1852): 1101-03. A critical edition of the review can be found in Ferdinand Břetislav Mikovec; Pražská Thálie kolem 1850, ed. Jitka Ludvová and Helena Pinkerová (Prague: Institut umění-Divadelní ústav, 2010), 205-08. On Mikovec's relationship to Eduard Hanslick, see David Brodbeck, Defining Deutschtum: Political Ideology, German Identity, and Music-Critical Discourse in Liberal Vienna (New York: Oxford University Press, 2014), 32 and $40-42$.
} 
evance of the utraquist approach to national culture in mid-nineteenth-century Prague; the Czech Figaro was announced and reviewed in both Czech and German-language press, and the cast was not only bilingual but included performers, such as Mink, who were mainly associated with the German-speaking theater.

\section{WERKTREUE IN SMETANA's Figaro at the Provisional Theater}

In the early 1860 s, the political situation in the Habsburg lands changed radically after the defeats of Austrian armies in Italy. The emperor Franz Joseph had to introduce constitutional changes to the imperial government, and these changes led to rapid development of Czech civic institutions, journals, and newspapers. In 1862 the Bohemian Provincial Council also provided state funds for the creation of a new Czech theater, which became the first Czech theater in Prague that was independent from the German theater and that also received state subventions. The 1862 state subvention served to construct a new building devoted solely to Czech-language performances. Because of the modest dimension of the new theater and because most Czech cultural leaders believed it would soon be replaced by a grand National Theater, the new institution was referred to as the Provisional Theater. The founders of the Provisional Theater did not foresee that the institution would stay active for over two decades, until the 1883 completion, after a circuitous process of collecting finances and a devastating fire, of the National Theater.

Mozart's operas were central for the repertoire of the Provisional Theater, and three of them, Don Giovanni, Die Zauberflöte, and Le nozze di Figaro, received numerous performances and several productions there. Possibly because Don Giovanni and Die Zauberflöte had a long tradition with Prague's Czech audiences and performers going back to the 1820s, the Czech versions of the two operas did not change too radically throughout the Provisional Theater period. ${ }^{65}$ Le nozze di Figaro, by contrast,

${ }^{65} \mathrm{As}$ in the case of Le nozze di Figaro, Jindřich Böhm also created a new Czech translation of Die Zauberflöte, which was published in 1875 but was apparently never used at had received only one performance in Czech prior to the establishment of the independent Czech theater, and its stage form therefore underwent substantial revisions during the Provisional Theater era, often in response to the changing artistic and political direction. This changing nature of Le nozze di Figaro becomes obvious from both the reviews of individual performances in contemporary journals and newspapers and the remnants of the performing materials used at the Provisional Theater: a prompter's score and a volume of a conducting score with the third act of the opera. The performing materials reflect the musical structure of Le nozze di Figaro as it was experienced by Czech audiences for several decades. ${ }^{66}$ For example, the scores show that during the Provisional Theater era, the opera was performed in two, as opposed to the original four, acts, and that to segue seamlessly between acts III and IV, the Czech productions repeated the March that opens the third-act finale. The scores were clearly no longer used once the Czech opera ensemble moved into the newly constructed National Theater; at that time, a new Czech adaptation was created, the text of that adaptation was not added to the Provisional Theater materials, and a new set of printed scores with handwritten Czech text came into use.

The Provisional Theater first performed $L e$ nozze di Figaro on 26 January 1865, when the company was under the direction of Jan Nepomuk Maýr. The performance was to commemorate Mozart's birthday (the celebration

the Provisional Theater. Kouzelná flétna, adapted for the Czech stage by Jindřich Böhm (Prague: Urbánek, 1875). For an overview of Mozartian performances at the Provisional Theater, see Josef Bartoš, Prozatímní divadlo a jeho opera (Prague: Sbor pro zř́izení druhého Národního divadla, 1938| and Václav Štěpán and Markéta Trávníčková, Prozatímní divadlo 1862-1883, vol. 1 (Prague: Academia, 2006), 222-40.

${ }^{66}$ Both the prompter's and the conducting scores are preserved in the National Theater Archive in Prague (H 120/ 18/1-2 and H120/P7). Many thanks to Matěj Dočekal and Aneta Peterová from the Archive for their erudite and friendly assistance in this research project. Besides the Figaro scores from the Provisional Theater, the National Theater Archive also preserves a prompter's libretto to Die Zauberflöte (National Theater Archive, H119/L24), which has entries dated from 1876 to 1882 and contains the Chmelenský translation from the 1820s; and a Donna Elvira part from the Provisional Theater period (National Theater Archive, H118/Part Proz. Div.). 
included festive illumination, according to the journal Politik). Such commemorative performances were common in both Czech and German theaters in Prague throughout the nineteenth century. Prague's opera companies commemorated not only Mozart's birthday but also the anniversaries of his death (5 December) and of the first performance of Don Giovanni $(29$ October). Maýr's 1865 performances of Le nozze di Figaro were reviewed in the journal Národní listy by Bedřich Smetana, who worked as a music critic there between 1864 and 1865. In his reviews, Smetana complained that Maýr's production omitted several musical numbers, thus indicating that he himself subscribed to the historicist views typical for Prague's approaches to Mozart since the late eighteenth century. ${ }^{67}$ Furthermore, when he eventually replaced Maýr as the Provisional Theater's opera director in 1866 and created a new production of Le nozze di Figaro (first performed on 6 November 1868), he was much more concerned about Werktreue than his predecessor.

The manuscript prompter's score clearly reflects the historicist changes that were executed in the opera under Smetana's leadership. For example, several pages of different paper were at some point inserted into the prompter's score, and they contain precisely those numbers that Smetana pointed out as missing in his 1865 reviews-most prominently the Andante (Fandango) section from the third-act finale $(\mathrm{mm}$. 132-74). Interestingly, Smetana never seems to have reinstated another cut that he complained about in 1865-that of mm. 118-32 in the second-act trio "Susanna, or via, sortite." Into the prompter's score someone, possibly Smetana, merely added a note in red crayon that points out the obvious: "schází" (missing). One of the most unusual aspects of Smetana's Le nozze di Figaro was his decision to include Don Basilio's fourth-act aria "In quegli'anni, in cui val poco," which was rarely performed in the nineteenth

\footnotetext{
${ }^{67}$ Smetana published two reviews of Le nozze di Figaro in Národní listy, on 28 January 1865 and 31 January 1865. The reviews were republished, with commentary, in Kritické dílo Bedřicha Smetany 1858-1865, ed. V. H. Jarka (Prague: Nakladatelství pražské akciové tiskárny, 1948), $154-56$.
}

century and is still cut from many present-day Figaro productions. That the aria became part of the opera is clear both from the fact that it was additionally inserted into the prompter's score and from an 1868 review in the journal Naše listy, praising Antonín Barcal's rendition of Basilio's "song in donkey's skin." ${ }^{68}$

Under Smetana's direction, Le nozze di Figaro achieved a similar level of symbolic importance for the emerging Czech cultural movement as Don Juan had earlier in the century. According to the Provisional Theater historian Josef Bartoš, Le nozze di Figaro became Smetana's signature Mozart production, one that continually attracted the attention of audiences and critics in Prague's newspapers. ${ }^{69}$ Even after the end of Smetana's directorship at the Provisional Theater, some of Prague's critics stressed the importance of the historicist approach to Le nozze di Figaro. In his review of the 22 April 1881 performance of Figaro at the Provisional Theater, the critic Emanuel Chvála wrote that due to the piety and love that Prague has always shown to Mozart, it is appropriate that the Provisional Theater performs the opera nearly in its entirety (with the exception of the duet "Aprite presto aprite" and Marcellina's "Il capro e la capretta")..$^{70}$ It would be even more appropriate, Chvála adds, if Marcellina's aria were added as well — a wish that was to remain unfulfilled for the rest of the nineteenth century.

\section{ETHNICITY AND THE Don Giovanni Centennial}

In the 1880s, Le nozze di Figaro, Don Giovanni, and Die Zauberflöte were featured prominently in the repertoire of both the exclusively German Estates Theater and the Czech National Theater, finally completed in 1883 after a devastating fire two years earlier. Most importantly,

\footnotetext{
${ }^{68 " L i t e r a t u r a}$ a umění. Divadlo," Naše listy, 10 November 1868.

${ }^{69}$ Bartoš, Prozatímní divadlo, 244. An example of the enthusiastic press reviews is the statement by Jan Ludevít Procházka, the critic of Naše listy, that Le nozze di Figaro is "the shining star in our operatic repertoire." "Literatura a umění: Divadlo," Naše listy, 19 November 1868.

${ }^{70}$ Emanuel Chvála, "Česká zpěvohra," Dalibor 3, no. 13 (1 May 1881): 103.
}

Prague 
the two institutions showcased the three operas (together with Die Entführung aus dem Serail, Idomeneo, and La clemenza di Titol in a series of festive performances in the fall of 1887, in commemoration of the Don Giovanni centennial. By then the Czech and German communities were coexisting in strictly separated spheres, and each of them used Mozart for different purposes that reflected the divergent national and ethnic ideologies and cultural policies.

Ethnic understanding of Mozart became particularly prominent in the debates about the centennial within Prague's German community. The decades leading up to the centennial brought important ideological changes among Prague's Germans. As the debates about Don Juan and authenticity in the 1830s and 1840s show, most German speakers in Prague still thought of themselves as Bohemians. But the discourse about Deutschtum in the Habsburg Empire radically changed after 1861; in reaction to the increasingly nationalistic Czech ideologies in Prague, many German intellectuals subscribed to liberal German nationalism, which preached the superiority of the German culture over other, especially Slavic, cultures of the Empire, but was willing to support members of the non-German cultural movements who wanted to join the Germanic efforts. ${ }^{71}$ As David Brodbeck has shown, the career and intellectual development of Eduard Hanslick exemplifies this development from Bohemian patriotism to liberal German nationalism: whereas in the late 1840s, while still living in Prague, Hanslick set to music at least two Czech poems, thus endorsing the hope for a bilingual Bohemia where Czech and German speakers flourished side by side, in his 1893 autobiography he sees Prague of the 1840s as a city of two distinct ethnic groups and the ethnic Czechs of that time and the following decades as benefiting from the superior German culture. ${ }^{72}$ The

\footnotetext{
${ }^{71}$ For an overview of these developments, see Pieter M. Judson, Exclusive Revolutionaries: Liberal Politics, Social Experience, and National Identity in the Austrian Empire, 1848-1914 (Ann Arbor: University of Michigan Press, 1996); and Jonathan Kwan, Liberalism and the Habsburg Monarchy, 1861-1895 (London: Palgrave Macmillan, 2013). ${ }^{72}$ Brodbeck, Defining Deutschtum, 25-52, and Brodbeck, "Hanslick's Smetana and Hanslick's Prague," Journal of the Royal Musical Association 134, no. 1 (2009): 1-36.
}

views of certain German nationalists in Austria and Bohemia radicalized even more around 1880, after a series of events that made the German-speaking subjects of the Austrian emperors feel threatened by what now appeared as a Slavic majority. ${ }^{73}$ In response to a series of pro-Czech measures by the conservative and federalist government of Eduard von Taaffe (such as the so-called Stremayr ordinance of 1880 that allowed the public in Bohemia and Moravia to conduct business with state officials not only in German but also in Czech), many German-speaking intellectuals in Austria adopted exclusivist ethnic viewpoints.

Such viewpoints are reflected in the Prague German debates about the Don Giovanni centennial in 1887. Throughout that whole year, both the Czech and German communities in Prague were preparing for the celebratory performances of Don Giovanni on 29 October $1887 .{ }^{74}$ In the spring of 1887 , the director of Prague's German theater, Angelo Neumann, announced that the festive performance on that day in the Estates Theater would present the opera in the Italian original. The decision became a source of controversy. First, Otto Brucks, the baritone who was supposed to sing the role of Don Giovanni, refused to learn his part in a language he did not speak. ${ }^{75}$ The critics of Prague's German newspapers, the Prager Tagblatt and the Prager Abendblatt, initiated a nationalistic campaign for a complete cancellation of the Italian performance. On 2 September 1887, the Prager Abendblatt reminded the readers that the German Prague was among the first communities to perform Wagner's operas and reject the "barbaric Verdi," and that it should now also reject Mozart in Italian. On 10

\footnotetext{
${ }^{73}$ Brodbeck, Defining Deutschtum, 6-11 and 159-61; Cohen, The Politics of Ethnic Survival, 66-68; and Jeremy King, Budweiser into Czechs and Germans: A Local History of Bohemian Politics, 1848-1948 (Princeton: Princeton University Press, 2005), 55-62.

${ }^{74}$ Basic information about the centennial in the German Theater can be found in Ludvová, Až k hořkému konci, 154-55.

${ }^{75}$ It is unclear whether Brucks's refusal was an expression of chauvinist viewpoints or a genuine fear of singing in an unknown language. As Ther points out, the requirement to sing in different languages became widespread only in the late 1890s and early 1900s. Ther, Center Stage, 23031.
} 
October 1887, furthermore, the Prager Tagblatt cited a statement, written with "true German sense," according to the Prague reporter, by the Berlin music critic Otto Gumprecht, who claimed that in Mozart's time opera could be in Italian because it was a luxurious commodity available only for the aristocratic elites, but the contemporary audience was "not aristocratic but democratic, not cosmopolitan but national" and therefore deserved Mozart's Don Giovanni in German. Notwithstanding the pressure from the press, Neumann went ahead with the Italian performance, staging a major publicity stunt by hiring the famous Spanish baritone Mariano Padilla y Ramos for the performance on 29 October. All the other performances of Mozart's opera returned to the German Don Juan. Clearly, the significance of authenticity had shifted by 1887: in 1842, the most prominent Prague critic thought of the Italian performance of Don Giovanni by the Conservatory ensemble as unusually stimulating, and throughout the 1840s, 50s, and 60s, the Prague opera company tried to restore the opera to its original form, but in 1887 similar attempts came to be viewed as un-German and anti-national by some. The progression of the canon toward greater autonomy in the nineteenth century was not a straightforward path and was heavily politicized.

Nationalistic views of Mozart as an inherently German composer also dominate Mozartrelated writings by Prague's German thinkers of the late nineteenth century. For example, in his festive speech in Prague's Rudolfinum the day after the centennial (30 October 1887), Guido Adler, then a professor at the Prague German University, stressed that although Mozart emulated the Italians in his opera, he kept "the true German heart" (das treue deutsche Herz) in his contacts with the alien, non-German world ("im Contact mit dem Fremden und in der Fremde selbst"), and his music is therefore "the purest treasure of the German spirit and the German culture" (der reinste Schatz deutschen Geistes und deutscher Kultur). ${ }^{76}$ Similar ideas underlie the most well-

${ }^{76}$ The speech is summarized in "Vom Tage. Die 'Don Juan' Jubiläums Feier der deutschen Vereine Prags," Prager Tagblatt, 31 October 1887. known nineteenth-century Bohemian study of Mozart, Rudolph Freiherr von Procházka's 1892 Mozart in Prag. Procházka, a German-Bohemian composer and music critic, imposes the new ethnic understanding of nationality onto Prague's cultural history. He presents Don Giovanni and Le nozze di Figaro as Mozart's attempts at creating German national opera, which he illustrates by quoting the composer's famous letter from 21 March 1785, expressing frustration about lacking support for German national opera in Vienna. ${ }^{77}$ Procházka then explains that Prague was much more open than Vienna to the idea of getting rid of the "Italian frippery" (italienischer Firlefanz), and that the citizens of Prague viewed Mozart as a "German Apollo" - he was indeed called that in a poem, published in Prague in 1787.78 According to Procházka, Don Giovanni was therefore a German national opera created for Prague, an eighteenth-century center of Germanness. Such views contrast with the earlier nineteenth-century approaches by German speakers in Prague, when Mozart would have most likely been viewed as an honorary Bohemian, not an ethnic German. The shift in understanding of Mozart among Prague's German writers corresponds to a general change in perspective among Prague's Germans who after 1848, and even more after 1861, started acquiring "a sense of belonging to a distinct German group defined essentially by language and culture." 79

Conspicuously missing from most of these discussions about the Prague German Don Giovanni are explicit references to the role of Czech speakers both in Prague's culture of the late eighteenth century and in present-day Prague. An expression of what the German writers possibly thought about Czech-language theater, and what remained unarticulated in the celebratory writings and speeches, appears in the preface to the second volume of Oscar Teuber's magisterial Geschichte des Prager Theaters, published in 1885. Teuber devotes two chapters to Mozart's visits to Prague in 1787

\footnotetext{
${ }^{77}$ Rudolph Freiherr Procházka, Mozart in Prag (Prague: Dominicus, 1892), 29 and 222.

${ }^{78}$ Ibid., 29.

${ }^{79}$ Cohen, The Politics of Ethnic Survival, 23.
}

Prague 
and 1791. In the book's preface, Teuber claims that early Czech theater does not merit serious consideration, as becomes obvious from an "objective" history based on "documentary or reliable literary sources" ("[es] ergibt sich . . . aus der objektiven, auf urkundlichen oder zuverlässigen literarischen Quellen fussenden Darstellung, dass die Leistungen der čechischen Dramatiker und Künstler in jenen bescheidenen Anfängen kaum Anspruch auf ernste Würdigung erheben können"). ${ }^{80}$ Teuber stresses that the late-eighteenth-century culture and society in Prague had an unmistakable German character. In reference to the political situation of the 1880s, furthermore, Teuber emphasizes that the German theater of Prague deserves attention "particularly today, when it struggles for survival under unfavorable social and national circumstances and under the threat of powerful competition from the Slavic culture that originated only recently and drew most of its original inspiration from it [German theater]" (gerade heute, wo sie unter ungünstigen socialen und nationalen Bedingungen, bedroht von der mächtigen Concurrenz einer neu entstandenen und im Grunde doch aus ihr hervorgewachsenen slawischen Kunstanstalt, den Kampf um ihr Dasein kampft). ${ }^{81}$

In the Czech camp, there were at least two distinct approaches to Mozart in the 1880s: an exclusivist, nationalistic one and a classicistic, sublimating one. Some Czech intellectuals in the early 1880s thought that Mozart was essentially an alien element within Czech cultural history. Such a view was the result of social processes initiated after the constitutional reforms of 1861, when the Czech nationalists started forming a new civic society based on the principles of ethnic identity. The incorporation of Mozart into this new understanding of Czechness became problematic because of the composer's purported German ethnicity. This change in perception did not necessarily impact the productions at the Provisional Theater because the opera company there for the most part reused the performing materials from

${ }^{80}$ Oscar Teuber, Geschichte des Prager Theaters, vol. 2 (Prague: Haase, 1885), ix.

${ }^{81}$ Ibid., $\mathrm{x}-\mathrm{xi}$. previous decades. The debates about the first production of Don Giovanni at the National Theater, however, illustrate the changing and more ambiguous attitudes to Mozart in the Czech cultural camp of the 1880s. The new production of Don Giovanni did not premiere at the National Theater until 27 September 1884 , the beginning of the second season. Considering the symbolic importance of Don Giovanni for Prague, many imagined that the opera would have been produced sooner-in fact, in his National Theater history, Zdeněk Nejedlý claims that some critics called for Don Giovanni to be the very first foreign-language opera to be presented at the new, national stage already in $1883 .{ }^{82}$ Instead, during its first season, the National Theater performed only original Czech operas and works by French and Italian authors, such as Verdi's Aida and Bizet's Carmen. In his essay about the National Theater's inaugural season, its first director, František Adolf Šubert, claimed that Don Giovanni was postponed until the second season because the stage sets were not finished in time. ${ }^{83}$ However, it is conspicuous that the other opera postponed until the second season, supposedly also due to issues with sets, was Wagner's Lohengrin. Šubert, furthermore, admits that he purposefully excluded German spoken plays from the National Theater repertoire in the first season to undermine the widespread idea that Czech culture is a branch of German culture and to support the national struggle against the "German element" |"hájíce sebe protiživlu německému"|. ${ }^{84}$ Although Šubert denies that Don Giovanni's place in the first season of the National Theater fell victim to ethnic and anti-German viewpoints, the fact that he mentions Mozart in the context of the postponed Lohengrin and the rejected German spoken works suggests that a portion of the Czech cultural elites now considered Mozart a foreign composer-for them, an honorary Bohemian had transformed into an ethnic German.

\footnotetext{
${ }^{82}$ Zdeněk Nejedlý, Dějiny opery Národního divadla, vol. 1 (Prague: Práce, 1949), 166.

${ }^{83}$ František Adolf Šubert, První rok v Národním divadle (Prague: Závod tiskařský a vydavatelský, 1884), 15. 84Šubert, První rok, 25
} 
These ethnic views were eventually overpowered by the tendency to perceive Mozart as a universal phenomenon, disconnected from Germanness. Such an approach went back to the Czech debates about Mozart in 1820s, when critics such as Chmelenský called for Czech performances to remove from Mozart's operas later, German "impurities." Into this universalist understanding of Mozart, moreover, Czech writers introduced ideas about specifically Czech contributions to Mozart's Prague achievements and about inherent links between Mozart and Czechness. In the celebratory ode written for the 1887 centennial, for example, the famous Czech poet Jaroslav Vrchlický compares Mozart's works solely to symbols of classical antiquity, such as the fire of Prometheus or the paradise gardens of the Hesperides. ${ }^{85}$ Vrchlicky's poem also suggests that Mozart stood as an archangel at the cradle of future victories for Czech national music. In this period, moreover, the idea became prominent that Mozart's music was spiritually connected to Czechness as reflected in purported affinities between Mozart's compositions and Czech folk musicthis idea continued to appear in twentieth-century scholarly studies. ${ }^{86}$

An example of how these classicizing sentiments could be nationalized and politicized can be found in the festive speech from 30 October 1887, delivered at the Czech cultural gathering in Bertramka, Mozart's supposed countryside retreat outside of Prague, by Jan Strakatý, the director of the Czech arts organization Umělecká beseda and the son of the bass Karel Stra-

\footnotetext{
${ }^{85 J a r o s l a v ~ V r c h l i c k y ́, ~ " M o z a r t o v i: ~ K ~ p a m a ́ t c e ~ p r v n i ́ h o ~}$ provozování Dona Juana," in Památce Mozartovè, ed. František Adolf Šubert (Prague: Družstvo Národního divadla, 1887), 3.

${ }^{86}$ Paul Nettl lists several Czech folk songs that have Mozartian tonal language ("Mozartsche Tonsprache") and contain melodic phrases ("Melodiefloskeln") that seem to be appropriated from Mozart's works. Paul Nettl, Mozart in Böhmen (Prague: Neumann, 1938), 224-25. In the later twentieth century, the idea that a spiritual connection exists between Mozart and Czech music and that Czech composers wrote in Mozartian manner even before Mozart is discussed in Marie Tarantová, "Ohlas díla W. A. Mozarta v českém obrození," in Zprávy Bertramky (Prague: Mozartova obec, 1967), 16.
}

katý-the first Czech Figaro. ${ }^{87}$ In the first part of the speech, Strakatý expresses common antiViennese viewpoints that had been appearing in Prague's debates about Mozart ever since Niemetschek. According to Strakatý, Mozart found a refuge in Prague "after having been spurned by the envy of his own fellow countrymen" (po trpkých ústrcích, jež připravovala mu závist vlastních krajanů). Unlike Procházka, however, Strakatý focuses on the rivalry between Prague and Vienna without making Prague into a center of German nationalism. Later, Strakatý in fact directly rejects the idea of Prague as a German city. He claims that while in Prague, Mozart thought he was among Germans, but that the city's inhabitants were in fact German-speaking Czechs, who could not speak Czech at the time because of the tragic history of their country. The people responsible for the creation of Don Giovanni, Strakatý implies, were patriots who would have honored Czech history and the Czech nation if they could. To demonstrate the inherent Czechness of the supposed German inhabitants of Prague during Mozart's time and the following decades, Strakatý pointed to the soprano Kateřina Podhorská, the star of Prague's German opera between 1819 and 1849, who also performed in Czech productions (including the role of Donna Anna in the very first Czech Don Juan of 1825). Podhorská was still alive to participate in the $1887 \mathrm{Czech}$, as opposed to the German, celebration of the centennial. It is clear, Strakatý continued, that had Mozart lived in 1887, he would have supported Czech interests and would not understand the claims of those who treated him as a German artist.

The classicistic, cosmopolitan, and pro-Czech view of Mozart did not necessarily revive the earlier concerns about Werktreue, so important for the generations from Štěpánek to Smetana. For example, although the 1887 adaptation of Le nozze di Figaro for the National Theater authored by the composer, music critic, and translator Václav Juda Novotný reintroduced recitatives for the first time in several ${ }^{87}$ The speech was printed in "Denní zprávy. Česká
Mozartova slavnost v Praze," Národní listy, 31 October 1887. 
decades, it dropped Don Basilio's fourth-act aria and reorganized the opera's structure, so that Barbarina's "L'ho perduto" and Figaro's "Aprite un po' quegli occhi" became the closing numbers of the third act. ${ }^{88}$ Similarly, Novotnýs 1884 arrangement of Don Giovanni changed the stage directions and the texts of the recitatives, especially in those places where Da Ponte's original was, in Novotný's words, too "trivial" and out of sync with the "exalted" style of the music. ${ }^{89}$ Novotný also claimed that the whole opera was too long for regular performances, and so certain sections, most prominently the scena ultima, could be left out and presented only on special occasions.

\section{Postlude}

Late-nineteenth-century views of Mozart in relation to Czech identity influenced cultural life in Prague for decades to come. A symbolic act expressing the idea that Mozart represented a foreign, Germanic, and therefore anti-Czech element occurred sometime in May 1945. After the liberation of Prague from the Nazis by the Red Army, the Czech authorities took possession of the New German Theater-the building that had replaced the Estates Theater as the main German opera house in Prague in $1888 .^{90}$ In the process of transforming the New German Theater into a Czech institution, called the Opera of the Fifth of May in commemoration of a recent anti-Nazi uprising in the city, the new owners took away not only the Nazi signs displayed on the façade and the 1888 German inscription dedicating the theater to the German people, but also the three busts of Goethe, Schiller, and Mozart placed prominently in three alcoves in between the front pillars.

\footnotetext{
${ }^{88}$ Figarova svatba, trans. and adapted for the Czech stage by Václav Juda Novotný (Prague: Družstvo Národního divadla, 1887).

${ }^{89}$ See Novotný's preface in Don Juan, trans. and adapted for the Czech stage by Václav Juda Novotný (Prague: Urbánek, 1884), 6-7.

${ }^{90}$ The New German Theater was originally supposed to be inaugurated with a festive performance of Don Juan on 30 October 1887, the day after the centennial. Due to construction delays, however, the theater eventually opened on 5 January 1888 with Wagner's Die Meistersinger.
}

Twentieth- and twenty-first-century Czech musicologists, by contrast, emphasized the notion of Mozart as a cosmopolitan, classical figure, possibly to undermine the composer's potentially sensitive connection to Prague's former Germanness. The doyen of Czech Mozart studies, Tomislav Volek, for example, on several occasions referred to nineteenth-century German adaptations of Mozart's operas in Prague as "degrading" and "embarrassing." 91 As recently as 2013, the late Czech musicologist Michaela Freemanová asked whether nineteenth-century arrangements of Mozart's operas should be "viewed . . . with contempt or valued as testaments of their time." ${ }^{\prime 92}$ For Volek, furthermore, the only nineteenth-century performances that really mattered were the student productions of the Italian originals led by Giovanni Gordigiani, the vocal pedagogue at the Prague Conservatory. The underlying assumption for Volek was that only museumlike performances of the Mozart-Da Ponte operas in their original language and with Italian recitatives did justice to Mozart's legacy and were worthy of scholarly study. Volek's rejection of nineteenth-century German Mozart productions, therefore, has to do with the concept of operatic autonomy and Werktreue, so prominent both in early-nineteenth-century Prague debates about Mozart and in twentieth-century opera scholarship and criticism in general. But the quasi-moralistic attitudes of twentieth-century Prague's Mozart researchers also grow out of an earlier Czech school of music criticism that was marked by a strong penchant for socially responsible, and morally uplifting, art. ${ }^{93}$ An important representative of this approach was the musicologist Vladimír Helfert, to whom Volek has professed an intellectual allegiance on numerous occasions. ${ }^{94}$ The strongly ideo-

\footnotetext{
${ }^{91}$ See Tomislav Volek, "Význam pražské operní tradice pro vznik Mozartovy opery Don Giovanni," in Mozartův Don Giovanni v Praze (Prague: Divadelní ústav, 1987), 88, and Volek, "Mozartovy italské opery," 442.

${ }^{92}$ Freemanová, "Bohemia in the Early 19th Century," 101.

${ }^{93}$ The origins of these aesthetic ideas are discussed in Brian Locke, Opera and Ideology in Prague: The Polemics and Practice at the National Theater, 1900-1938 (Rochester: University of Rochester Press, 2006), 5-6 and 24-26.

${ }^{94}$ See, for example, Tomislav Volek, "Helfert stále aktuální," Opus musicum 18, no. 10 (1986): 306-10; and his Helfert biography in Mozart, die italienische Oper des
} 
logical approach of Czech musicologists to Mozart shows that the composer's relationship to Prague is still central to Czech cultural identity. The study of the nineteenth-century receptions of Le nozze di Figaro and Don Giovanni in the Bohemian capital, therefore, not only affords a unique cultural perspective on the social and political developments of Prague's multiethnic communities, but also illuminates why these works continue to matter in the present day.

18. Jahrhunderts und das musikalische Leben im Königreich Böhmen; mit der Don-Juan-Studie von Vladimír Helfert, ed. Milada Jonášová and Matthias J. Pernerstorfer (Vienna: Hollitzer, 2017), xxi-xxxv.

\section{Abstract.}

After the enormous success of Le nozze di Figaro at Prague's Nostitz Theater in 1786 and the world premiere of Don Giovanni there in 1787, Mozart's operas became canonic works in the Bohemian capital, with numerous performances every season throughout the nineteenth century. These nineteenth-century Prague Mozart productions are particularly well documented in the previously overlooked collection of theater posters from the Czech National Museum and the mid-nineteenth-century manuscript scores of Le nozze di Figaro. Much sooner than elsewhere in Europe, Prague's critics, audiences, and opera institutions aimed at historically informed, "authentic" productions of these operas. This article shows that the attempts to transform Mozart's operas into autonomous artworks, artworks that would faithfully reflect the unique vision of their creator and not succumb to changing audience tastes, were closely linked to national politics in nineteenthcentury Prague. As the city's population became more and more divided into ethnic Czechs and Germans, both groups appropriated Mozart for their own narratives of cultural uniqueness and cultivation. The attempts at historic authenticity originated already in the 1820s, when Czech opera performers and critics wanted to perform Don Giovanni in a form that was as close as possible to that created by Mozart in 1787 but distorted in various German singspiel adaptations. Similar attempts at historical authenticity are also prominent in Bedřich Smetana's approach to Le nozze di Figaro, during his tenure as the music director of the Czech Provisional Theater in the late 1860s. German-speaking performers and critics used claims of historical authenticity in the 1830 s and 40 s to stress Prague's importance as a prominent center of German culture. During the celebrations of the 1887 Don Giovanni centennial, furthermore, both the Czech and German communities in Prague appropriated Mozart's operas into their intensely nationalistic debates. Keywords: Mozart, Prague, Czech, and German nationalism 